\title{
Correction to: Morbidity and mortality in patients managed with high compared with low blood pressure targets during on- pump cardiac surgery: a systematic review and meta-analysis of randomized controlled trials
}

\section{Correction à: Morbidité et mortalité des patients pris en charge avec des cibles élevées ou basses de pression artérielle pendant la chirurgie cardiaque sous circulation extracorporelle : une revue systématique et une méta-analyse d'études randomisées contrôlées}

\author{
Charlotte C. McEwen, MD • Takhliq Amir, BHSc(Hons) • Yuan Qiu, BHSc(Hons) • \\ Jack Young, MLIS • Kevin Kennedy, MA • Hilary P. Grocott, MD, FRCPC, FASE • \\ Hessam Kashani, MD, MSc • David Mazer, MD, FRCPC • Scott Brudney, MBChB, FRCPC • \\ Morvarid Kavosh, MD • Eric Jacobsohn, MBChB, MPH, FRCPC • Anne Vedel, MD, PhD • \\ Eugene Wang, MD • Richard P. Whitlock, MD, PhD, FRCSC • \\ Emilie P. Belley-Coté, MD, PhD, FRCPC • Jessica Spence, MD, PhD, FRCPC
}

Published online: 14 February 2022

(C) Canadian Anesthesiologists' Society 2022

\section{Correction to:}

Can J Anesth/J Can Anesth

https://doi.org/10.1007/s12630-021-02171-3

This article was updated to correct Hessam Kashani's name.

The original article can be found online at https://doi.org/10.1007/ s12630-021-02171-3.

C. C. McEwen, MD

Department of Surgery (Cardiac Surgery), McMaster University, Hamilton, ON, Canada

T. Amir, BHSc(Hons) - Y. Qiu, BHSc(Hons) - E. Wang, MD Faculty of Health Sciences, McMaster University, Hamilton, ON, Canada

J. Young, MLIS

Health Sciences Library, McMaster University, Hamilton, ON, Canada

\section{K. Kennedy, MA}

Department of Health Research Methods, Evaluation, and

Impact, McMaster University, Hamilton, ON, Canada
H. P. Grocott, MD, FRCPC, FASE - H. Kashani, MD, MSc . M. Kavosh, MD Department of Anesthesia and Perioperative Medicine, University of Manitoba, Winnipeg, MB, Canada

D. Mazer, MD, FRCPC

Department of Anesthesia, Li Ka Shing Knowledge Institute, St. Michael's Hospital, Toronto, ON, Canada

Department of Anesthesiology and Pain Medicine, University of Toronto, Toronto, ON, Canada

S. Brudney, MBChB, FRCPC - E. Jacobsohn, MBChB, MPH, FRCPC

Departments of Medicine (Critical Care) and Anesthesia and Perioperative Medicine, University of Manitoba, Winnipeg, MB, Canada 
Publisher's Note Springer Nature remains neutral with regard to jurisdictional claims in published maps and institutional affiliations.

A. Vedel, MD, PhD
Department of Cardiothoracic Anesthesiology, Copenhagen

University Hospital, Copenhagen, Denmark

R. P. Whitlock, MD, PhD, FRCSC

Departments of Surgery (Cardiac Surgery) and Health Research Methods, Evaluation, and Impact, McMaster University,

Hamilton, ON, Canada

Perioperative Research Division, Population Health Research Institute, Hamilton, ON, Canada

E. P. Belley-Coté, MD, PhD, FRCPC

Perioperative Research Division, Population Health Research Institute, Hamilton, ON, Canada

Departments of Medicine (Cardiology and Critical Care) and Health Research Methods, Evaluation, and Impact, McMaster University, Hamilton, ON, Canada

J. Spence, MD, PhD, FRCPC ( $\square)$

Perioperative Research Division, Population Health Research Institute, Hamilton, ON, Canada

e-mail: jessicaspence13@gmail.com

Departments of Anesthesia and Critical Care and Health Research Methods, Evaluation, and Impact, McMaster

University, Hamilton, ON, Canada 